\title{
Sürdürülebilir Gelişmede Yerel Halkın Rolü: Urla Örneği
}

Araştırma Makalesi /Research Article

\section{Elif DİKMEN DİRIÖZ ${ }^{1}$}

\section{Mükerrem ARSLAN ${ }^{2}$}

ÖZ: Bu çalı̧̧mada, çevre politikalarının temelini oluşturan "sürdürülebilir gelişme" kavramı, çevre ve ekonomik gelişme ilişkileri ve sürdürülebilir gelişmede yerel halkın rolü göz önüne alınarak Urla örneği değerlendirilmektedir. Sürdürülebilir gelişme, insanların yaşam koşullarını daha iyiye götürebilecekleri bir gelişme biçimi sunmaktadır. Bu kapsamda, araştırmada öncelikle, sürdürülebilirlik kavramı ve kent örnekleri ele alınmıştır. Ardından araştırma, kentlerde sürdürülebilir gelişme sağlanabilmesi için yerel halkın rolünü ve önemini irdelemektedir. Bu bağlamda, sürdürülebilir gelişme sağlanmasinda politikalara ilaveten, yerel halkın rolü ve önemini anlamak için Urla örneği ele alınmıştır. Urla'daki yerel halkın çevre bilincini ölçmek amacıyla, yöntem olarak anket çalışması yapılmıştır. Urla'da yaşayan yerel halkın bilgi ve eğitim düzeyi, sürdürülebilir kalkınma için önemli bir unsurdur.

Anahtar Kelimeler: Sürdürülebilirlik, Sürdürülebilir Gelişme, Yerel Halk, Yerel Yönetim, Çevre Bilinci

JEL Kodu: Q00, Q01, Q56, R00, R11

\section{The Role of Local Citizens in Sustainable Development:}

\section{The Case of Urla}

\begin{abstract}
This study, evaluates the Urla case by considering the concept of "sustainable development". The relationship between environmental and economic development and the role of local people in sustainable development were evaluated. Sustainable development offers a form of development in which people can improve their living conditions. In this context, the concept of sustainability and urban examples are discussed first. The research then examines the role and importance of local people in achieving sustainable development in cities. In this context, the case of Urla was selected to understand the role and importance of local people, in addition to policies, in achieving sustainable development. As a method to measure environmental awareness of the local population in Urla, a survey was conducted. The level of knowledge and education of local people living in Urla is an important element for Sustainable Development.
\end{abstract}

Keywords: Sustainability, Sustainable Development, Local Citizens, Local Government, Environmental Awareness

JEL Codes: Q00, Q01, Q56, R00, R11

Geliş Tarihi / Received: 15/10/2019

Kabul Tarihi / Accepted: 17/02/2020

1 Doktora Öğrencisi, Ankara Üniversitesi, Ziraat Fakültesi, Peyzaj Mimarlığı Bölümü, elifdkmn@yahoo.com, orcid.org/0000-0001-8674-3347

2 Prof. Dr., Ankara Üniversitesi, Ziraat Fakültesi, Peyzaj Mimarlığı Bölümü, muarslan@ankara.edu.tr, orcid.org/0000-0003-0131-7985 


\section{Giriș}

Bu çalışmanın amacı, sürdürülebilir gelişmede yerel halkın rolünü, İzmir'in Urla ilçesi örneğini kullanılarak belirlemektir. Bu amaçla, Urla'daki yerel halkın "sürdürülebilirlik" kavramı hakkındaki bilgi düzeyi anketlerle ölçülmüştür. Literatür taramasıyla, sürdürülebilir gelişmenin nasıl sağlanacağı hakkında öneriler incelenmiştir. Ayrıca istatistiksel açıdan anlamlı sayıda katılımcıyla yürütülen anketlerle, yerel halkın sürdürülebilir kalkınma ile ilgili bilgi düzeyi araştırılmıştır. Yapılan anketler yerel halkın etkinliklere katılma potansiyelini ortaya çıkarmaktadır. Son yıllarda, çevrenin korunmasında, doğanın limitlerine saygı duyulması yer almaktadır. Yakın gelecekteki gelişimlerin temelini, sürdürülebilir tasarımlar oluşturmaktadır. Sürdürülebilirlikte sistematik düşünce gereklidir; parçaları değil bütünü görmek, belli özellikler arasındaki ilișkileri fark etmek, fiziksel yapının işlenmesi ve değiştirilmesini sağlamak, sayıya değil kaliteye önem vermek ve dişlayan değil kapsayan bir yaklaşım gereklidir (Cole vd., 2000: 22-24).

Dünya, hızla kentleşmekte ve kentlerde yaşayan nüfus her geçen yıl artmaktadır. Kent bilimleri ile ilgilenen disiplinler, kentlerin herkes için daha yaşanabilir hale gelebilmesi için en doğru olan çözümleri tartışmak ve araştırmak durumundadır. Yeşil kent kavramı; kent ve kentin yakın çevresinin vejetasyon ile kaplanmasından; temiz enerji kullanılmasını, araba bağımlılı̆̆ının azaltılmasını, kent ve bölge planlamasından, ekolojik yapı tasarımına kadar oldukça kapsamlı ve farklı önceliklerle ifade edilmektedir (Uslu, 2009: 49-58). Literatürde sürdürülebilir gelișme kavramına, Birleșmiș Milletler'in belirlediği Sürdürülebilir Kalkınma Hedeflerine, Avrupa yeşil kentlerine, sürdürülebilir gelişme ile yerel halk ilişkisine yer verilmiştir.

Çalışmanın amacı, İzmir'in Urla İlçesi'nin sürdürülebilir gelişme potansiyelini saptamak ve Urla'da yaşayan yerel halkın sürdürülebilirlik, sürdürülebilir gelişme hakkındaki bilgi düzeyini, çevre bilincini ve yerel yönetimden beklentilerini belirleyebilmektir. Çalışma, giriş ve sonuç bölümleri hariç, üç bölümden oluşmaktadır. Birinci bölüm sürdürülebilir gelişme, sürdürülebilir kalkınma hedefleri, Avrupa yeşil kentleri ve yerel halk ilişkisini ortaya koyan literatür taramasından oluşmaktadır. İkinci bölümde araştırmanın amacı, veri toplama yöntemi ve Urla'da yaşayan yerel halka uygulanan anket çalışmasının sonuçları yer almaktadır. Üçüncü bölümde ise, Urla bölgesinde sürdürülebilir gelişme sağlanabilmesi için potansiyeller ortaya konmaktadır.

\section{Sürdürülebilir Gelişme}

"Sürdürülebilir Gelişme", Kent Bilim Terimleri Sözlüğünde, "...doğal kaynakların akılcı yöntemlerle, gelecek kuşakların haklarını göz önünde bulundurarak kullanılması, ekonomik gelişmenin sağlanmasını amaçlayan çevreci dünya görüşü" olarak açıklanmaktadır (Bozlağan, 2005: 1012-1013). Sürdürülebilir gelişme kavramının önem kazandığı ve ilk resmi tanımının 
yapıldığı asıl belge, Dünya Çevre ve Gelişim Komisyonu tarafından hazırlanan ve 1987 yılında yayımlanan, "Ortak Geleceğimiz (Brundtland) Raporu” dur (Kılıçoğlu, 2005: 79).

Birleşmiş Milletler Sürdürülebilir Kalkınma Konferansı (Rio+20), 20-22 Haziran 2012 tarihinde, Brezilya'nın Rio de Janeiro kentinde gerçekleştirilmiştir. Bu konferansın amaçlarından birisi, ülkelerin sürdürülebilir kalkınmaya yönelik hedeflerinin geliştirilmesidir. Konferansındaki tartışmalar sonucunda, "İstediğimiz Gelecek" adlı konferans sonuç belgesi kabul edilmiştir (Birleşmiş Milletler Sürdürülebilir Kalkınma Konferansı 2012). Bu belge, 2015 yılı sonrası için Sürdürülebilir Kalkınma Hedeflerini içerir. Ayrıca bu belge, yeşil büyüme, kentler, istihdam, enerji, su, denizler, afetler, gıda gibi önemli konuları belirlemektedir.

Yukarıda belirtilen "İstediğimiz Gelecek" raporunun sürdürülebilir kent ve yerleşimler ile ilgili maddesi de önemlidir (Birleşmiş Milletler Sürdürülebilir Kalkınma Konferansı 2012). İyi bir şekilde planlanan ve gelişen kentlerin, ekonomik, sosyal ve çevresel açıdan sürdürülebilir toplumların oluşumunu destekleyeceği kabul edilmiştir. Kentte yaşayan insanların yaşam koşullarının daha iyi olması için, onların yaşam kalitelerinin geliştirilmesi için çalışılacağ1 söylenmiştir (Birleşmiş Milletler Sürdürülebilir Kalkınma Konferansı 2012). Yerel yönetimleri destekleyecek, kamu bilincini yükseltecek, karar alma sürecine yerel halkı da dahil edecek sürdürülebilir şehirler ve kentsel yerleşimleri planlamaya yönelik bütünleşik bir yaklaşım teşvik edilmiştir.

Belediyelerin, sürdürülebilir kent vizyonu oluşturulmasında çok önemli bir rolü vardır. Belediyeler, kent planlarının ilk aşamasından başlayarak yapılarda enerjinin etkin kullanımı, yerel koşullara uygun sürdürülebilir ulaşım sistemlerinin geliştirilmesi, eski kentsel alanların canlandırılması gibi alanların gelişmesi için çalışmalıdır. Aynı zamanda taşıt trafiğinin azaltılıp yaya bölgelerinin artması, toplu taşıma sistemlerinin geliştirilmesi, bisiklet yollarının düzenlenmesi gibi konular da önemlidir (Birleşmiş Milletler Sürdürülebilir Kalkınma Konferans1 2012). Sürdürülebilirlik sürekli olarak değişim gösteren muhtelif faktörlerin (ekonomik, sosyal, çevre) arasında bir dengeleme gerektirmektedir. Sürdürülebilir gelişme politikalarında temel amaç, yaşam kalitesini yükseltirken çevre ile entegre olmuş politikalar kullanmaktır (Pearce ve Vanegas 2002: 59). Günümüzde, kentlerde nüfusun artması ve sanayileşme sonucunda meydana gelen çevre kirliliği, doğal kaynakların yok edilmesi tüm toplumlarda problemler yaratmış ve gelecek ile ilgili kaygılar oluşturmuştur (Atıl, Gülgün ve Yörük 2005: 223).

Küreselleşme ile birlikte ulusal ve uluslararası çevre politikalarının temelini oluşturan "sürdürülebilir gelişme" kavramı, çevre ve ekonomik gelişme ilişkisi içerisinde değerlendirilmektedir. Küreselleşme ve kentlerde nüfusunun artması ile birlikte insanoğlu, bazı kaynakların devamlılığını sağlamak için yeni arayışlar içine girmiştir. Son yıllarda farklı disiplinler arasında sıklıkla önemi vurgulanan 
"sürdürülebilirlik" ve "gelişme" kavramlarının farklı disiplinler tarafından farklı tanımlamaları yapılmaktadır. Sürdürülebilir gelişme, kendi yaşam kalitemizi yükseltirken, çevrenin bozulmasına ve başka insanların yaşam standartlarının düşmesine yol açmamaktadır (Pearce ve Vanegas 2002: 54-55).

Son dönemde dünyada yaşanan ekonomik problemler, iklim değişikliği gibi çevresel problemler "sürdürülebilir kalkınma" çerçevesi altında yeşil büyüme, yeşil ekonomi, düşük karbonlu ekonomi, sürdürülebilir üretim ve tüketim gibi kavramları ortaya çıkarmıştır (surdurulebilirkalkinma.gov.tr). Dolayısıyla, dünyada kabul gören, sürdürülebilir kalkınmanın yollarından biri olarak kabul edilen yeşil büyüme (ya da yeşil ekonomi), kalkınmanın meydana getirdiği olumsuz çevresel ve ekolojik etkileri yavaşlatmayı ve ekonomik kalkınmanın sürekliliğinin sağlanmasını hedeflemektedir. Birleşmiş Milletler Çevre Programı'na göre yeşil ekonomi, bir taraftan çevresel riskleri ve ekolojik yıpranmaları azaltırken, diğer taraftan da insan refahını artırıp sosyal eşitliği sağlayan sonuçlara sahiptir (Pezikoğlu, 2016: 1391-1392). Bu bağlamda, dünya çapında örnek uygulamalar arasında Avrupa yeşil kentleri de bulunmaktadır. Bir sonraki bölümde Avrupa yeşil kentleri irdelenmektedir.

\section{Avrupa Yeşil Kentleri}

Dünyadaki yeşil kent kriterleri ile ilgili iyi örnekler teşkil ettikleri için Avrupa Yeşil kentlerindeki uygulamaları incelemek, Türkiye'deki kentlere öneriler getirebilmek açısından önemlidir. 2006 yılında Avrupa Komisyonu, çevre dostu şehirleri değerlendirmek ve ödüllendirmek üzere bir ekip oluşturmuştur. Halkın yaşam kalitesini geliştirme hedefiyle başlatılan bu girişim kapsamında 50'den fazla şehir yarışmıştır. Stockholm, 2010 yılında yapılan değerlendirme sonucu Avrupa yeşil başkenti seçilmiştir. 2011 yılında ise Hamburg, Avrupa yeşil başkenti olarak ilan edilmiştir. AB komisyonu 2012 yılında İspanya Bask Bölgesi başkenti Vitoria-Gasteiz'i; 2013 y1lında ise Nantes'i (Fransa) ödüllendirerek Avrupa Yeşil Başkent sıfatına layık görülmüştür (Yücel Işıldar, 2012: 254). Toplu ulaşımın anadamarı olan metro hatlarına ilaveten, bisiklet yolları, yayalara ayrılmış kent merkezleri ve eko mimari örnekleriyle Hamburg, modern bir metropol olarak büyük kentler için önemli bir örnektir. Ulaşım konusunda örnek olarak Amsterdam gösterilirken, temiz havasıyla örnek olan Oslo, gürültü kirliliği ile etkin mücadele bakımından da Stockholm ilk sırada yer almaktadır. Hamburg ise, atık su, iklim ve çevre yönetimi konularında Avrupa'nın en iyisidir (Yücel Iş1ldar, 2012: 255).

Avrupa'daki Yeşil Kentler, birçok açıdan model olarak kabul edilebilirler. $\mathrm{Bu}$ bağlamda, Avrupa'daki yeşil kentlerin birçoğunda daha az araç trafiği, buna karşın daha fazla toplu taşımacılık, yaya ve bisiklet kullanımına yönelik uygulamalar göze çarpmaktadır. Örneğin Kopenhag'da ve birçok şehirde son 30 yılda bisikletle işe gidenlerin sayısı iki kat artmıştır (Gaslin 2013: 204). Bu bağlamda, Roodman (1999) yerel ve ulusal yönetimlerin yanı sıra, özel sektörün, sivil toplum 
kuruluşlarının ve vatandaşların, sürdürülebilir bir toplum yaratmak için birbirlerine destek olmaları gerektiğini ifade etmektedir.

Sürdürülebilirliğin kamu ve karar vericiler tarafından kavramsallaştırılmasında, yerel halk, esnaf, STK'lar ve diğer özel sektör kuruluşlarıyla yürütülen diyaloglar önem taşımaktadır. Yerel yönetimlerin, vatandaşlarla diyalog ve bilgi alışverişinde bulunmaları, sürdürülebilirlik anlayışının gelişmesine katkıda bulunmaktadır (Zeemering, 2009: 248-249). Capdevila ve Zarlenga (2015) 'ya göre, Barselona örneğinde olduğu gibi, tabandan gelen talep ile tepeden gelen politikalar birbirleriyle tamamlayıcı olduklarında, sinerji yaratılıp kentin sürdürülebilir gelişimine birçok açıdan katkıda bulunulması mümkündür.

AB- Yeşil Kent ve Halk işbirliği örnekleri incelenirken, Barselona'da yerel halkın güçlü bir yerel yönetimle temsil edildiği gözlemlenmektedir. Bir kentin sürdürülebilirlik hedefleri ilk bakışta ekonomik kar mantığıyla tamamen uyumlu gözükmeyebilir (Capdevila ve Zarlenga, 2015: 277). Ancak Barselona örneğinde olduğu gibi, inovatif sürdürülebilir ekosistem tasarlanmasında toplumun farklı kesimleri, vatandaşlar, özel sektör ve kamu, bir araya gelip sürdürülebilir ve inovatif bir kent gelişim bütünsel planlamasına yönelik hedeflerde ortak stratejiler etrafında anlaşabilirler (Capdevila ve Zarlenga, 2015: 270-271). Bir kentin sürdürülebilir olmasındaki en önemli etkenlerin başında, o kentte yaşayan yerel halk gelmektedir.

Ekonomik güce sahip olan Amerika Birleşik Devletleri, uluslararası çevre koruma anlaşmalarının hazırlanmasında ve uygulanmasında çok önemli bir potansiyele sahiptir. Seattle kenti, geçmişte iklim değişikliği, kışın sel baskınları, yazın kuraklık ve orman yangınları gibi sorunlarla mücadele etmekteydi. Bu nedenle 2005 yılında Seattle Belediye Başkanı kentin sera gazı emisyonunun azaltılmasına yönelik İklim Eylem Planı girişimini başlatmıştır. İklim Eylem Planı çalışmaları Yeşil Kurdele Komisyonu tarafından gerçekleştirilmiştir. Yeşil Kurdele Komisyonunda özel sektör, kamu yönetimi ve sivil toplum temsilcileri yer almıştır. Bu komisyonunun amacı, iklim değişikliği ile mücadele edebilmek için politikalar ve programlar önermekti (Uysal Oğuz 2010: 29-30).

Yeşil Kurdele Komisyonunun hazırladığı raporda Eğitim Alt Komitesi bulunmaktadır. Eğitim Alt Komitesi, sera gazı emisyonunun azaltılmasında kent halkının rol alabilmesi için önemli eğitim programlarına yer vermektedir. $\mathrm{Bu}$ komite ayrıca, sosyal dayanışma stratejileri de belirlemektedir. İklim Eylem Planı'nın hedeflerinden birisi de halkın kampanyalarla bilinçlendirilmesi ve problemlerin çözüm arayışlarına katılımlarının teşvik edilmesidir. İklim Eylem Planında hedeflenen sera gazı emisyonunun azaltılmasında, ilgili sektörler sorumluluk almış, kent halkı da bu sürece katılım göstermiştir (Uysal Oğuz 2010: 32-34). 


\section{Türkiye'de Urla Örneği}

Urla İzmir'in 32 km batısında, kendi adını taşıyan yarımadanın merkezinde, İzmir ilçeleri arasında önemli bir yere sahiptir. Tarihi, antik çağlara dayanan Urla'da birçok yöresel ürün bulunmaktadır. Urla'da var olan yöresel ürünlerin zenginliği çeşitli festivallerin yapılmasına ve yerel halkın kalkınmasına olanak sağlamaktadır. Urla'daki doğal zenginlikleri tanıtma ve koruma amacıyla yerel halk tarafından birçok etkinlikler düzenlenmektedir. "Uluslararası Kıyı ve Deniz Temizliği Etkinliği", "Geleneksel Urla Mart Dokuzu Ot Festivali", Uluslararası Enginar Festivali, Bağ Bozumu Şenlikleri, Kavun Festivali, Oyuk Festivali yerel halk tarafindan yapılan etkinliklerdir. Bu festivaller bölge turizmine de önemli katkı sağlamaktadır. Festivallerin amaçları arasında yerel halkın kalkınması dışında; doğal, kültürel, tarihi özelliklerin korunması ve tanıtılması da bulunmaktadır. Örneğin, Urla'da yapılan Zeytin Hasadı Festivalinin amacı tarihten gelen değerlerin tanıtılması, gelecek nesillere aktarılmasıdır. Ayrıca, bölgede yaşayan kadınların ekonomik anlamda güçlenebilmesi ve topluma kazandırılması ve yerel halkın kalkınması için Kadın Üretici Pazarı bulunmaktadır.

\subsection{Araştırmanın Amacı}

Araştırma alanı olarak seçilen Urla, İzmir ilçeleri arasında önemli bir yere sahiptir. Eski bir yerleşim yeri olan Urla'da çok sayıda tarihi eser bulunmaktadır. Urla tarihi ve arkeolojik sit alanlarının yoğun olduğu bir bölgedir. Urla gelişirken, doğal, tarihi ve kültürel kaynaklarının korunması da büyük önem taşımaktadır. Urla'nın sahip olduğu doğal, tarihi, kültürel kaynaklar, Urla'da yaşayan yerel halkın üretimleri ve Urla'da gerçekleştirdikleri etkinlikler sürdürülebilir gelişme açısından ciddi potansiyeller oluşturmaktadır. Bu doğrultuda araştırmanın amacı, İzmir'in Urla İlçesi'nin sürdürülebilir gelişme potansiyelini belirlemek ve Urla'da yaşayan yerel halkın sürdürülebilirlik, sürdürülebilir gelişme hakkında bilgi düzeyini, yerel halkın çevre bilincini ve yerel halkın yerel yönetimden olan beklentilerini belirleyebilmektir.

\subsection{Veri Toplama Yöntemi}

$\mathrm{Bu}$ araştırmada öncelikle literatür taraması yapılmış ve yurt dışından sürdürülebilir gelişme ve yerel halk arasındaki ilişkinin önemini yansıtan örnekler ele alınmıştır. Urla'da yaşayan yerel halkın sürdürülebilirlik, sürdürülebilir gelişme hakkında bilgi düzeyini, yerel halkın çevre bilincini ve yerel halkın yerel yönetimden olan beklentilerini belirleyebilmek amacıyla anket çalışması yapılmıştır. Araştırma kapsamında anket çalışması, çeşitli araştırmalarda kullanılan ve bir kentin sürdürülebilir olabilmesi için gereken kriterler düşünülerek hazırlanmıştır. 181 kişi ile gerçekleştirilen anket sonuçlarının güvenilirliği irdelenmiştir. Araştırma, Urla bölgesinde yaşayan yerel halka uygulanmıştır. Araştırma sonuçlarımız doğrultusunda Urla'da yaşayan yerel halkın sürdürülebilirlik ve sürdürülebilir gelişme konuları ile ilgili tespitlere dair yorum yapmaya elverişli bulgular sunabileceğine karar verilmiştir. 


\subsection{Anket Analizleri}

Araştırmanın ilk bölümünde, yerel halkın yaş, cinsiyet, eğitim düzeyi, iş, kişisel aylık gelir, Urla'da ikamet etme süresi ve Urla'da yaşama nedeni gibi bilgileri gösteren demografik istatistikler yer almaktadır. Bu istatistikler, katılımcıların evreni temsil yeteneğine dair bilgi verebilmesi ve ölçümlenen olguların demografik özelliklere göre değişkenliğini göstermesi açısından önemlidir. Araştırma sorularının cevaplanabilmesi için ihtiyaç duyulan önemli bilgi türü de Urla'da yaşayan yerel halkın sürdürülebilir gelişme hakkında bilgi sahibi olmalarıdır. $\mathrm{Bu}$ nedenle, anket çalışmasının ilk bölümünde katılımcılara sürdürülebilir gelişme hakkında fikirleri olup olmadığı sorulmuştur. Araştırma kapsamında, örnekleme dahil edilen yerel halkın cinsiyet, yaş, eğitim düzeyi, sürdürülen iş, ikamet süresi ve katılımcıların cinsiyete göre dağılımı gösterilmiştir. Araştırmaya toplamda 181 katılımcı dahil edildi.

Grafik 1: Katılımcıların Cinsiyet Dağı1ımı

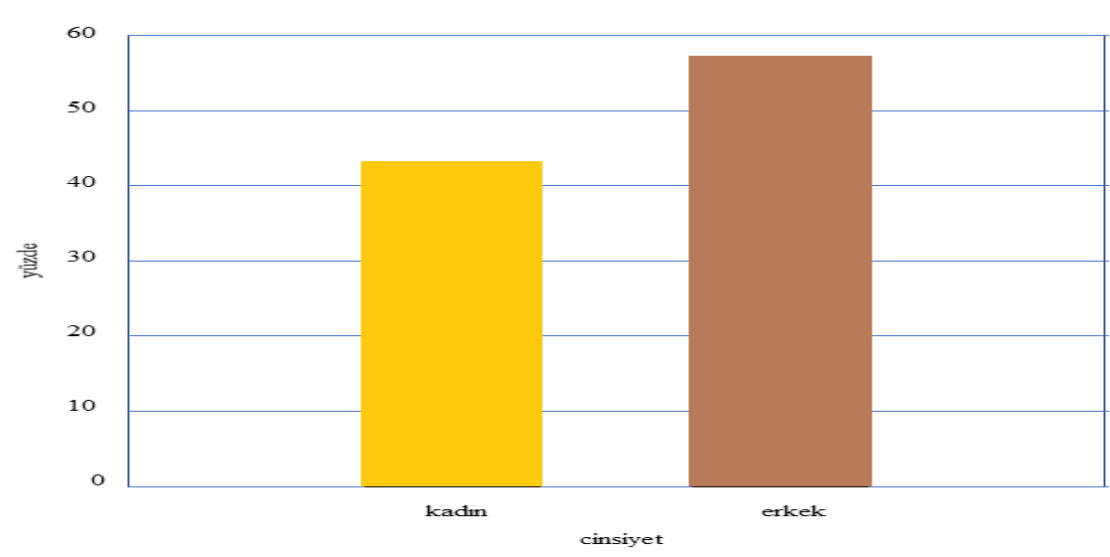

Grafik 1'de görüldüğü gibi, Katılımcılar ve kişisel bilgileri incelendiğinde \%43,1'inin kadın \%56,9'unun erkek olduğu tespit edilmiştir. Bu oran Urla'daki toplam kadın-erkek nüfus oranlarıyla uyumludur. $\mathrm{Bu}$ durumda katılımcilar arasında kadın ve erkeklerin temsil etme oranının dengeli olduğu düşünülmüştür.

Öte yandan, katılımcılar yaşlarına göre incelendiğinde çoğunun 30-44 yaş aralığında olduğu tespit edilmiştir.

Tablo 1: Katılımcıların Yaş Dağılımları

\begin{tabular}{|l|c|c|c|c|c|}
\hline Yaş Aralığ1 & $18-29$ & $30-44$ & $45-60$ & $60+$ & \\
\hline Say1 & 46 & 76 & 45 & 14 & 181 \\
\hline Yüzde & 25,4 & 41,9 & 24,9 & 7,9 & 100 \\
\hline
\end{tabular}

Tablo 1'de ve Grafik 2'de gösterildiği gibi; 181 katılımcının, \%25,4'ünün 18-29 yaş arasında olduğu, \%41,8'inin 30-44 yaşları arasında olduğu, \%24,9'unun 45-60 yaşları arasında olduğu ve \%7,9'unun ise 60 yaş ve üzeri olduğu görülmüştür. 
Katılımcıların eğitim durumlarının incelenmesi, bölgedeki sürdürülebilir kalkınma potansiyelinin anlaşılması bakımından önemli bir unsurdur.

Grafik 2: Katılımcıların Yaş Dağılımları

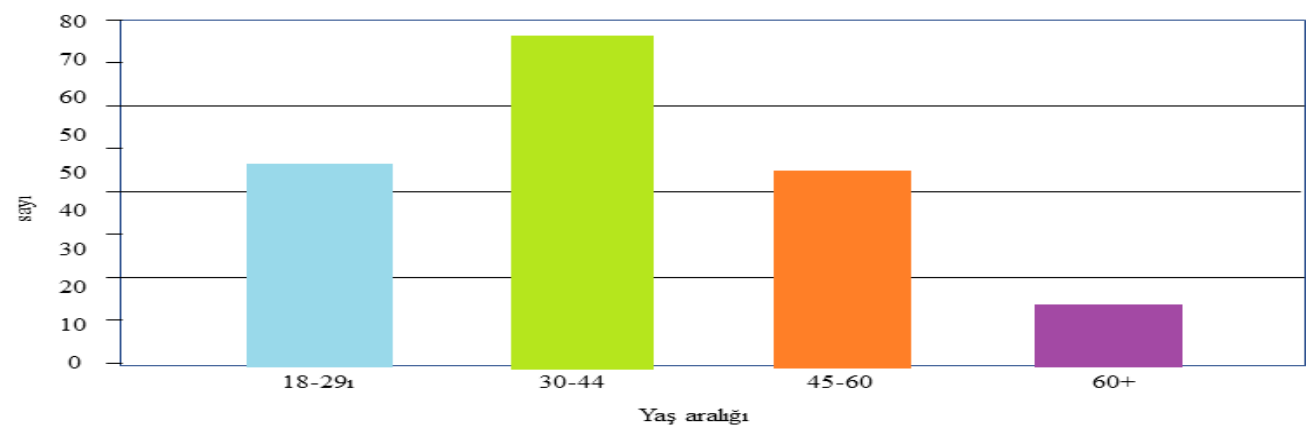

Tablo 2'den anlaşılabileceği gibi, katılımcıların vermiş olduğu bilgiler doğrultusunda; 181 katılımcının \%2,2'si okulu bitirmediği, \%11,1'inin ilköğretim, \%10,6'sının ortaöğretim, \%23,8'inin lise, \%43,3'ünün üniversite ve \%9,4'ünün ise yüksek lisans mezunu olduğu saptanmıştır.

Tablo 2: Katılımc1ların Eğitim Durumları

\begin{tabular}{|l|c|c|c|c|c|c|}
\hline $\begin{array}{l}\text { Eğitim } \\
\text { Seviyesi }\end{array}$ & $\begin{array}{c}\text { Okul } \\
\text { Bitirmemiş }\end{array}$ & İlköğretim & Orta & Lise & Üniversite & $\begin{array}{c}\text { Yüksek } \\
\text { Lisans }\end{array}$ \\
\hline Say1 & 4 & 20 & 19 & 43 & 78 & 17 \\
\hline Yüzde & 2,2 & 11,1 & 10,6 & 23,8 & 43,3 & 9,4 \\
\hline
\end{tabular}

Katılımcıların eğitim seviyelerinin tespitinin ardından yapılan anketlerle çalışma statüleri belirlenmiştir ve ankete katılanların çoğunun bir işyerinde çalışan olduğu tespit edilmiştir.

Tablo 3: Katılımcıların Çalışma Statüsü Dağılımları

\begin{tabular}{|l|c|c|c|c|c|c|c|}
\hline & İşveren & $\begin{array}{c}\text { Kendi } \\
\text { İşi }\end{array}$ & $\begin{array}{c}\text { Çalışan } \\
\begin{array}{c}\text { Aile } \\
\text { işletmesinde } \\
\text { ücretsiz } \\
\text { çalışan }\end{array}\end{array}$ & $\begin{array}{c}\text { Mevsimlik } \\
\text { Çalışan }\end{array}$ & Çalışmayan & Diğer \\
\hline Say1 & 26 & 24 & 22 & 43 & 78 & 17 & 8 \\
\hline Yüzde & 14,4 & 13,3 & 12,0 & 23,8 & 43,3 & 9,4 & 4,4 \\
\hline
\end{tabular}

Tablo 3'deki bilgilere göre 181 katılımcıların işleri araştırıldığında, \%51,4'ünün çalışan, \%14,4'ünün işveren olduğu, \%13,3'ünün kendi işinde çalıştığı, \%12,7'sinin çalışmadığı, \%3,3'ünün aile işletmesinde ücretsiz çalıştığ $\% 0,6$ 'sının ise, mevsimlik çalışan olduğu saptanmıştır. Ayrıca, 181 katılımcının $\% 4,4$ 'ü bu soruya sunulan seçeneklerden başka bir meslek statüsünde olduğunu söylemiştir.

Mesleklerin aktiflik statüsü ayrıntılı incelendiğinde en büyük çoğunluğun hizmet sektöründe olduğu anlaşılmaktadır. 
Tablo 4: Katılımcıların Meslek Statüsü Dağılımları

\begin{tabular}{|c|c|c|c|c|c|c|}
\hline & $\begin{array}{c}\text { Bilim } \\
\text { sektörü }\end{array}$ & Memur & $\begin{array}{c}\text { Ticaret ile } \\
\text { uğraşan }\end{array}$ & $\begin{array}{c}\text { Hizmet } \\
\text { sektörü }\end{array}$ & Diğer & $\begin{array}{c}\text { Eksik } \\
\text { (Cevaplamad1) }\end{array}$ \\
\hline Say1 & 26 & 24 & 22 & 78 & 8 & 14 \\
\hline Yüzde & 8,7 & 4,1 & 15,7 & 30,8 & 34,3 & 6,4 \\
\hline
\end{tabular}

Tablo 4'den anlaşılabileceği gibi, aktif bir meslek statüsünde olan 172 katılımc1 çalıştığı sektörlere göre incelendiğinde, katılımcıların \%30,8'inin hizmet, \%15,7'sinin ticaret ile uğraştığı, \%8,7'sinin bilim sektörü çalışanı olduğu, $\% 4,1$ 'nin ise memur olduğu anlaşılmıştır. Öte yandan, bu soruya yanıt veren katılımcıları \%34,3'ü ise bu sektörlerin dışında bir sektörde yer aldıklarını belirtmişlerdir.

Aktif çalışma durumundan sonra da bölgenin sosyoekonomik yapısı hakkında genel bilgi sahibi olmak adına katılımcıların gelir düzeyi analiz edilmiştir. Ankete katılanların çoğunun orta gelirli olduğu saptanmıştır.

Tablo 5: Katılımc1ların Gelir Durumları

\begin{tabular}{|c|c|c|c|c|}
\hline & $\begin{array}{c}\text { Asgari ücret } \\
\text { ve alt1 }\end{array}$ & $2000-4000$ & $4000-6000$ & $6000+$ \\
\hline Say1 & 38 & 62 & 37 & 44 \\
\hline Yüzde & 21,0 & 34,2 & 20,4 & 24,3 \\
\hline
\end{tabular}

Tablo 5'deki veriler incelendiğinde, katılımcılar gelir durumlarına göre incelendiğinde, 181 katılımcının \%20,8'inin asgari ücret ve altında, \%34,2'sinin 2000 ile $4000 \mathrm{TL}$ arasında, \%20,2'sinin 4000 ile $6000 \mathrm{TL}$ arasında, \%24,3'ünün ise 6000 TL ve üzerinde gelirinin olduğu anlaşılmıştır.

Bölge halkının genel sosyoekonomik ve eğitim düzeyi belirlendikten sonra, sürdürülebilir gelişme hakkındaki görüşleri incelenmiştir. Çoğunluğun sürdürülebilir gelişme ile ilgili bir fikrinin olduğu görülmüştür.

Tablo 6: Katılımcıların Sürdürülebilir Gelişme Hakkında Fikri Olup Olmaması

\begin{tabular}{|c|c|c|c|c|c|}
\hline \multicolumn{2}{|c|}{} & Frekans & Yüzde & Geçerli Yüzde & $\begin{array}{c}\text { Kümülatif } \\
\text { Yüzde }\end{array}$ \\
\hline \multirow{2}{*}{} & Evet & 95 & 52,5 & 53,4 & 53,4 \\
\cline { 2 - 6 } & Hayır & 83 & 45,9 & 46,6 & 10,00 \\
\cline { 2 - 6 } & Toplam & 178 & 98,3 & 100,0 & \\
\hline Cevapsız & & 3 & 1,7 & & \\
\hline \multicolumn{2}{|c|}{ Toplam } & 181 & 100,0 & & \\
\hline
\end{tabular}

Tablo 6'dan anlaşılabileceği gibi, katılımcıların \%52,5'i sürdürülebilir gelişme hakkında bir fikri olduğunu belirtirken, \%45,9'u aksi yönde bir cevap belirtmiştir. \%1,7'si ise bu soruya cevap vermemiştir. Bu sorunun devamında, evet diyen katılımcılara yerel yönetimin sürdürülebilir gelişme hakkında etkinlikler yapıp yapmadığı sorulmuştur. 
Tablo 7: Yerel Yönetimin Sürdürülebilir Gelişme Etkinlikleri Yapıp Yapmaması Görüşü

\begin{tabular}{|c|c|c|c|c|c|}
\hline \multicolumn{2}{|c|}{} & Frekans & Yüzde & Geçerli Yüzde & Kümülatif Yüzde \\
\hline \multirow{4}{*}{ Evet } & 58 & 32,0 & 58,6 & 58,6 \\
\cline { 2 - 6 } & Hayır & 41 & 22,7 & 41,4 & 100,0 \\
\cline { 2 - 6 } & Toplam & 99 & 54,7 & 100,0 & \\
\hline Cevapsız & & 82 & 45,3 & & \\
\hline \multicolumn{2}{|c|}{ Toplam } & 181 & 100,0 & & \\
\hline
\end{tabular}

Tablo 7'de görüldüğü gibi, bir önceki soruya evet diyen katılımcıların \%58,6's1 bölgelerin de yerel yönetimin sürdürülebilir gelişme ile ilgili etkinlikler yaptığını söylerken, \%41,4'ü ise bu tarz etkinliklerin yapılmadığını söylemektedir. Ardından sürdürülebilir gelişme hakkında fikir sahibi olan katılımcıların yerel yönetimin etkinliklerini yeterli bulup bulmadıkları sorulmuştur.

Tablo 8: Yerel Yönetimin Sürdürülebilir Gelişme Etkinliklerinin Yeterliliği

\begin{tabular}{|c|c|c|c|c|c|}
\hline \multicolumn{2}{|c|}{} & Frekans & Yüzde & Geçerli Yüzde & Kümülatif Yüzde \\
\hline \multirow{4}{*}{} & Evet & 23 & 12,7 & 24,7 & 24,7 \\
\cline { 2 - 6 } & Hayır & 70 & 38,7 & 75,3 & 100,0 \\
\cline { 2 - 6 } & Toplam & 93 & 51,4 & 100,0 & \\
\hline Cevapsız & & 88 & 48,6 & & \\
\hline \multicolumn{2}{|c|}{ Toplam } & 181 & 100,0 & & \\
\hline
\end{tabular}

Tablo 8 incelendiğinde, sürdürülebilir gelişme hakkında fikir sahibi olan katılımcıların sadece \%24,7'si yerel yönetimin sürdürülebilir gelişme ile ilgili etkinliklerini yeterli bulmamaktadır. Bu konuda halkın katılımının daha fazla olması gerektiği düşüncesi de hâkimdir.

Tablo 9: Yerel Halkın Sürdürülebilir Gelişme Kararlarında Yer Alması

\begin{tabular}{|c|c|c|c|c|c|}
\hline \multicolumn{2}{|c|}{} & Frekans & Yüzde & Geçerli Yüzde & $\begin{array}{c}\text { Kümülatif } \\
\text { Yüzde }\end{array}$ \\
\hline \multirow{2}{*}{ Evet } & 37 & 20,4 & 41,1 & 41,1 \\
\cline { 2 - 6 } & Hayır & 53 & 29,3 & 58,9 & 100,0 \\
\cline { 2 - 6 } & Toplam & 90 & 49,7 & 100,0 & \\
\hline Cevapsız & & 91 & 50,3 & & \\
\hline \multicolumn{2}{|c|}{ Toplam } & 181 & 100,0 & & \\
\hline
\end{tabular}

Tablo 9 incelendiğinde, sürdürülebilir gelişme hakkında fikir sahibi olan katılımcıların \%41,1'i yerel halkın, yerel yönetimin "sürdürülebilir gelişme" ile ilgili kararlarında yer aldığını ifade ederken, büyük çoğunluk aksi yönde beyanda bulunmuştur Ayrıca, halen yerel halkın çoğu sürdürülebilir gelişme etkinliklerine katılmamaktadır. 
Tablo 10: Halkın Yerel Yönetimin Sürdürülebilir Gelişme Etkinliklerine Katılımı

\begin{tabular}{|c|c|c|c|c|c|}
\hline \multicolumn{2}{|c|}{} & Frekans & Yüzde & Geçerli Yüzde & Kümülatif Yüzde \\
\hline \multirow{4}{*}{} & Evet & 30 & 16,6 & 31,9 & 31,9 \\
\cline { 2 - 6 } & Hayır & 64 & 35,4 & 68,1 & 100,0 \\
\cline { 2 - 6 } & Toplam & 94 & 51,9 & 100,0 & \\
\hline Cevaps1z & & 87 & 48,1 & & \\
\hline \multicolumn{2}{|c|}{ Toplam } & 181 & 100,0 & & \\
\hline
\end{tabular}

Tablo 10'dan anlaşıldığı gibi, sürdürülebilir gelişme hakkında fikir sahibi olan katılımcıların \%31,9'u yerel yönetimin sürdürülebilir gelişme ile ilgili etkinliklerinde yer aldığını söylerken, \%68,1'i yer almadığını belirtmiştir. Buna karşın, sürdürülebilir gelişme hakkına bilgi sahibi olmayan katılımcıların çoğu, konu hakkında etkinlik yapılmasını istemiştir.

Tablo 11: Yerel Yönetimin Sürdürülebilirlik Etkinlikleri Düzenleme Gerekliliği

\begin{tabular}{|c|c|c|c|c|c|}
\hline \multicolumn{2}{|c|}{} & Frekans & Yüzde & Geçerli Yüzde & Kümülatif Yüzde \\
\hline & Evet & 154 & 85,1 & 90,1 & 90,1 \\
\cline { 2 - 6 } & Hayır & 17 & 9,4 & 9,9 & 100,0 \\
\cline { 2 - 6 } & Toplam & 171 & 94,5 & 100,0 & \\
\hline Cevapsiz & & 10 & 5,5 & & \\
\hline \multicolumn{2}{|c|}{ Toplam } & 181 & 100,0 & & \\
\hline
\end{tabular}

Tablo 11'de görülebileceği üzere, sürdürülebilir gelişme hakkında bilgi sahibi olmayan katılımcıların \%90,1'i yerel yönetimin sürdürülebilir gelişme ile ilgili etkinlikler yapması gerektiğini düşünürken \%9,9'u gerekmediği konusunda fikir belirtmiştir.

Tablo 12: Halkın, Sürdürülebilir Gelişme Etkinliklerinde Yer Alması Gerekliliği

\begin{tabular}{|c|c|c|c|c|c|}
\hline \multicolumn{2}{|c|}{} & Frekans & Yüzde & Geçerli Yüzde & Kümülatif Yüzde \\
\hline \multirow{4}{*}{ Cevapsız } & Evet & 151 & 83,4 & 92,1 & 92,1 \\
\cline { 2 - 6 } & Hayır & 13 & 7,2 & 7,9 & 100,0 \\
\cline { 2 - 6 } & Toplam & 164 & 90,6 & 100,0 & \\
\hline \multicolumn{2}{|c|}{ Toplam } & 17 & 9,4 & & \\
\hline
\end{tabular}

Tablo 12 incelendiğinde, katılımcıların $\% 83,4$ 'ü yerel halkın, yerel yönetimin düzenlemiş olduğu sürdürülebilir gelişme etkinliklerinde yer alması gerektiğini düşünürken, \%7,2'si aksi yönde fikir beyan etmiştir. Öte yandan, 181 katılımcının $\% 9,4$ 'ü ise bu soruyu yanıtsız bırakmıştır.

Tablo 13: Katılımcıların Sürdürülebilir Gelişme Etkinliklerine Katılma İstekleri

\begin{tabular}{|c|c|c|c|c|c|}
\hline \multicolumn{2}{|c|}{} & Frekans & Yüzde & Geçerli Yüzde & Kümülatif Yüzde \\
\hline \multirow{4}{*}{} & Evet & 142 & 78,5 & 85,0 & 85,0 \\
\cline { 2 - 6 } & Hayır & 25 & 13,8 & 15,0 & 100,0 \\
\cline { 2 - 6 } & Toplam & 167 & 92,3 & 100,0 & \\
\hline Cevapsız & & 14 & 7,7 & & \\
\hline \multicolumn{2}{|c|}{ Toplam } & 181 & 100,0 & & \\
\hline
\end{tabular}


Tablo 13'de görüldüğü gibi, katılımcıların \%78,5'i sürdürülebilir gelişme ile ilgili etkinlikler yapılırsa, bu etkinliklere katılacaklarını belirtirken, \%13,8'i katılmayacaklarını söylemiştir. Öte yandan, 181 katılımcının \%7,7'si ise bu soruya herhangi bir yanıt vermemiştir.

Tablo 14: Yerel Yönetimin Sürdürülebilir Gelişme Etkinlikleri Gerekliliği

\begin{tabular}{|c|c|c|c|c|c|}
\hline & & Frekans & Yüzde & Geçerli Yüzde & $\begin{array}{c}\text { Kümülatif } \\
\text { Yüzde }\end{array}$ \\
\hline & \begin{tabular}{|l|} 
Tamamen \\
Katıllyorum
\end{tabular} & 23 & 12,7 & 13,1 & 13,1 \\
\hline & Katıliyorum & 36 & 19,9 & 20,6 & 33,7 \\
\hline & Karars1z & 62 & 34,3 & 35,4 & 69,1 \\
\hline & Katılmıyorum & 44 & 24,3 & 25,1 & 94,3 \\
\hline & Hiç Katılmıyorum & 10 & 5,5 & 5,7 & 100,0 \\
\hline & Toplam & 175 & 96,7 & 100,0 & \\
\hline Cevapsiz & & 6 & 3,3 & & \\
\hline & Toplam & 181 & 100,0 & & \\
\hline
\end{tabular}

Grafik 3: Yerel Yönetimin Sürdürülebilir Gelişme Etkinlikler Gerekliliği

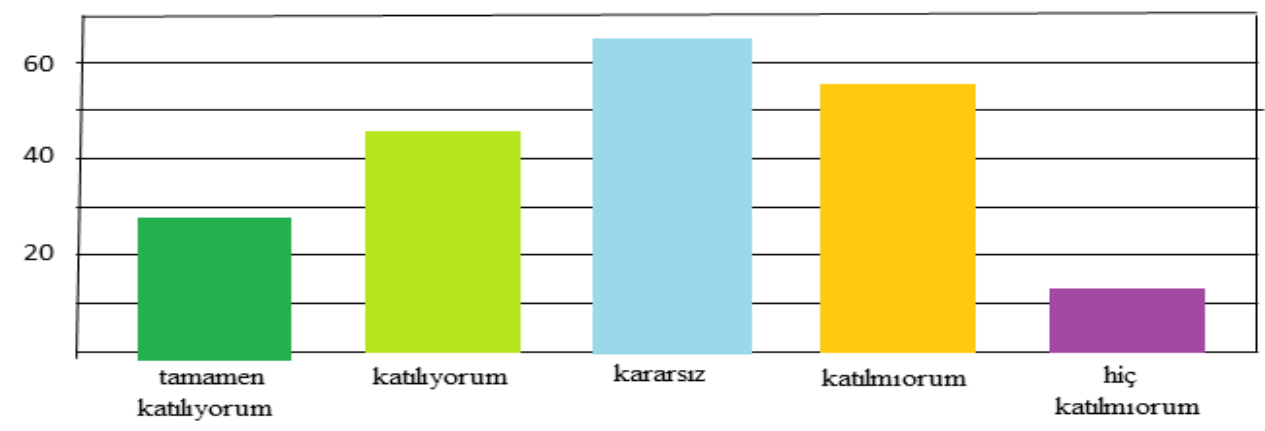

Tablo 14'de ve Grafik 3'de görüleceği gibi, katılımcıların bölgelerinde yerel yönetimin sürdürülebilir gelişme ile ilgili etkinlikler yapıp yapmaması gerektiği ile ilgili görüşü ile ilgili sonuçlar Tablo 14'de ve Grafik 3'de verilmiştir. Katılımcıların \%33,7'si bölgedeki doğal, tarihi ve kültürel kaynakların korunduğunu düşünürken, \%30,8'i bu yargıya katılmadığını beyan etmiştir. $\mathrm{Bu}$ yargı hakkında, katılımcıların \%34,3’ü kararsız olduklarını söylemiştir.

Tablo 15: Yenilenebilir Enerji Kaynaklarından Faydalanma

\begin{tabular}{|c|c|c|c|c|c|}
\hline & Frekans & Yüzde & Geçerli Yüzde & Kümülatif Yüzde \\
\hline & Evet & 65 & 35,9 & 36,9 & 36,9 \\
\hline & Hayır & 111 & 61,3 & 631 & 100,0 \\
\hline & Toplam & 176 & 97,2 & 100,0 & \\
\hline Cevapsız & & 5 & 2,8 & & \\
\hline To & & 181 & 100,0 & & \\
\hline
\end{tabular}


Tablo 15'de incelendiği zaman, çalışmada yer alan 181 katılımcının \%35,9'u bölgelerinde yenilenebilir enerji kaynaklarından yararlanırken, \%61,3'lük gibi büyük bir kesiminin yenilenebilir enerji kaynaklarından yararlanmadığ 1 tespit edilmiştir. Öte yandan katılımcıların \%2,8'i bu soruyu yanıtsız bırakmıştır.

Tablo 16: Hangi Tür Yenilenebilir Enerji Kaynaklarından Yararlanıyor

\begin{tabular}{|c|l|c|c|c|c|}
\hline \multicolumn{2}{|c|}{} & Frekans & Yüzde & Geçerli Yüzde & Kümülatif Yüzde \\
\hline \multirow{7}{*}{ Güneş } & 33 & 18,2 & 50,0 & 50,0 \\
\cline { 2 - 6 } & Rüzgâr & 9 & 5,0 & 13,6 & 63,6 \\
\cline { 2 - 6 } & Su & 12 & 6,6 & 18,2 & 81,8 \\
\cline { 2 - 6 } & Jeotermal & 2 & 1,1 & 3,0 & 84,8 \\
\cline { 2 - 6 } & Diğer & 10 & 5,5 & 15,2 & 100,0 \\
\cline { 2 - 6 } & Toplam & 66 & 36,5 & 100,0 & \\
\hline \multicolumn{1}{|c|}{ Cevaps1z } & 115 & 63,5 & & \\
\hline \multicolumn{2}{|c|}{ Toplam } & 181 & 100,0 & & \\
\hline
\end{tabular}

Grafik 4: Hangi Tür Yenilenebilir Enerji Kaynaklarından Yararlanıyor

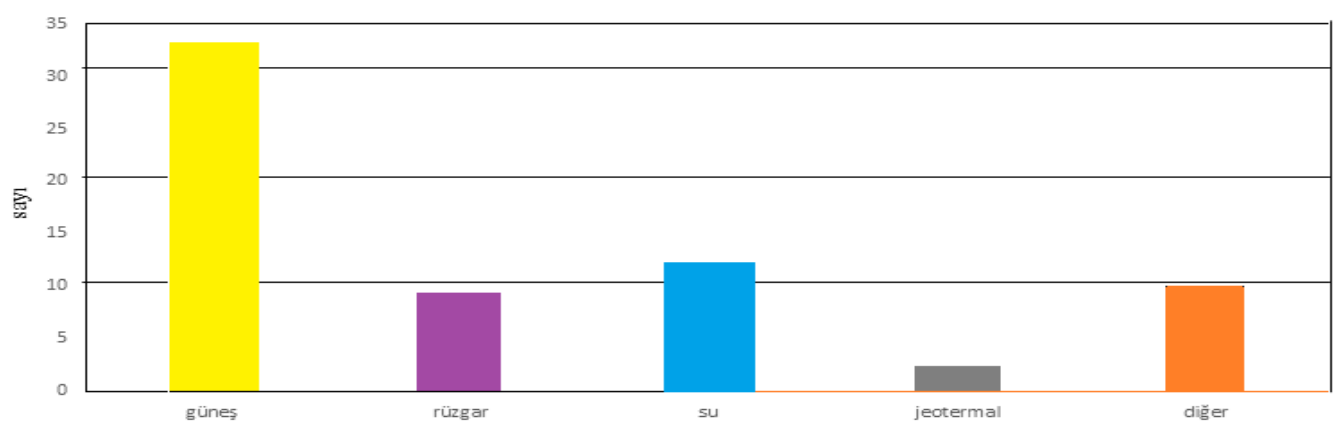

Tablo 16 ve Grafik 4'den anlaşılacağı gibi, yenilenebilir enerji kaynağı kullanan katılımcıların yarısı güneş enerjisinden faydalanırken, \%18,2'si su, \%13,6's1 rüzgâr ve \%3'üjeotermal enerjiden faydalanmaktadır. Öte yandan katılımcıların \%15,2'si ise sunulan seçeneklerin dışında bir yenilenebilir enerji kaynağı kullandığını belirtmiş̧tir.

Tablo 17: Yerel Yönetimin Alt Yapı Hizmetleri Değerlendirmesi

\begin{tabular}{|c|c|c|c|c|c|}
\hline \multicolumn{2}{|c|}{} & Frekans & Yüzde & Geçerli Yüzde & Kümülatif Yüzde \\
\hline \multirow{6}{*}{} & 0 & 49 & 27,1 & 29,0 & 29,0 \\
\cline { 2 - 6 } & 1 & 42 & 23,2 & 24,9 & 53,8 \\
\cline { 2 - 6 } & 2 & 37 & 20,4 & 21,9 & 75,7 \\
\cline { 2 - 6 } & 3 & 26 & 14,4 & 15,4 & 91,1 \\
\cline { 2 - 6 } & 4 & 10 & 5,5 & 5,9 & 97,0 \\
\cline { 2 - 6 } & 5 & 5 & 2,8 & 3,0 & 100,0 \\
\cline { 2 - 6 } & Toplam & 169 & 93,4 & 100,0 & \\
\hline Cevaps1z & & 12 & 6,6 & & \\
\hline \multicolumn{2}{|c|}{ Toplam } & 181 & 100,0 & & \\
\hline
\end{tabular}


Tablo 17 'de görüldüğ̈̈ gibi, katılımcıların $\% 8,3$ 'ü yerel yönetimin alt yap1 ile ilgili hizmetlerini iyi olarak değerlendirirken, $\% 43,8$ 'i ise yönetimin bu konudaki hizmetini yeterli bulmamaktadır. Katılımciların \%14,4'ü ise bu konuda belediyenin hizmetini orta seviyede görmektedir. Öte yandan 181 katılımcının $\% 27,1$ 'i belediyenin bu konuda hiçbir hizmeti olmadığını belirtirken, \%6,6'sı ise bu soruya yanıt vermemiştir.

Tablo 18'den anlaşılacağı gibi, katılımcıların \%22,1'i yerel yönetimin ulaşım ile ilgili hizmetlerini iyi olarak değerlendirirken, \%40,9'u yönetimin bu konudaki hizmetini yeterli bulmamaktadır. Katılımcıların \%25,4'ü ise bu konuda belediyenin hizmetini orta seviyede görmektedir. Öte yandan 181 katılımcının $\% 11$ 'i belediyenin bu konuda hiçbir hizmeti olmadığını belirtirken, $\% 6,6$ 'sı ise bu soruya yanıt vermemiştir.

Tablo 18: Yerel Yönetimin Ulaşım Hizmetleri ile İlgili Görüş

\begin{tabular}{|c|c|c|c|c|c|}
\hline \multicolumn{2}{|c|}{} & Frekans & Yüzde & Geçerli Yüzde & Kümülatif Yüzde \\
\hline & 0 & 20 & 11,0 & 11,8 & 11,8 \\
\cline { 2 - 6 } & 1 & 29 & 16,0 & 17,2 & 29,0 \\
\cline { 2 - 6 } & 2 & 40 & 22,1 & 23,7 & 52,7 \\
\cline { 2 - 6 } & 3 & 46 & 25,4 & 27,2 & 79,9 \\
\cline { 2 - 6 } & 4 & 26 & 14,4 & 15,4 & 95,3 \\
\cline { 2 - 6 } & 5 & 8 & 4,4 & 4,7 & 100,0 \\
\cline { 2 - 6 } & Toplam & 169 & 93,4 & 100,0 & \\
\hline
\end{tabular}

Urla'da yerel halkın sürdürülebilir gelişme etkinliklerine katılımının artması, sürdürülebilir gelişmenin sağlanabilmesi için büyük önem taşımaktadır. Yapılan anket çalışması sonucunda, Urla'daki yerel halkın sürdürülebilir gelişme sağlayabilecek potansiyele sahip olduğu anlaşılmaktadır. Urla'da yaşayan yerel halkın eğitim düzeyi ve sürdürülebilir gelişme ile ilgili bilgi düzeyinin yüksek olması, bu potansiyeli güçlendirmektedir. Bölgede yaşayan halkın önemli bir bölümünün sürdürülebilir gelişme ile ilgili etkinliklere katılmasına karşın, çoğunluğun katılmadığı ancak katılmak istediği de anlaşılmaktadır. Yapılan araştırma sonucu, yerel halkın yerel yönetimden, gerek yenilenebilir enerji kullanımını, gerek ulaşım konusunda bir beklenti içinde olduğu sonucuna varılmaktadır. Halkın genel eğitim ve bilgi düzeyinin yüksek olmasından dolayı Urla'da, sürdürülebilir gelişme ile ilgili yapılacak çalışmalara yerel halkın destek olma potansiyelinin yüksek olduğu anlaşılmaktadır. Ancak bu potansiyelin başarılı bir şekilde uygulanabilmesi için yerel yönetim, sivil toplum örgütleri ve yerel halk karar alma ve uygulama süreçlerinde birbirleriyle işbirliği halinde çalışmalılardır. 


\section{Sonuç}

Günümüzde, kentlerde nüfusun artması ve sanayileşme sonucunda meydana gelen çevre kirliliği, doğal kaynakların yok edilmesi gibi problemler insanoğlunda gelecek ile ilgili kaygıların oluşmasına neden olmuştur. Küreselleşme ile birlikte, çevre politikalarının temelini oluşturan sürdürülebilir gelişme kavramı çevre ve ekonomik gelişme ilişkisi içerisinde değerlendirilmektedir. Kentlerde nüfusun artması sonucunda kaynaklarının devamlılığını sağlamak için yeni arayışlar devam etmektedir. Bu arayışların amacı, yaşam kalitesini yükseltmek için çevreci politikalar kullanarak hedeflenen sosyoekonomik düzeye erişmektir. Araştırmada, kapsamlı olan Yeşil Kent kavramının farklı unsurları değerlendirilmiştir. $\mathrm{Bu}$ çerçevede Uslu'nu yeşil kent konuları olarak saydığı (2009: 49-58) farklı konular ele alınmıştır. Kent içinde ve kentin yakın çevresindeki vejetasyon ile kaplanması; temiz enerji kullanımı, motorlu bireysel binek araçların kullanılması ile kent ve bölge planlaması ölçeklerinden, çevre etkinliklerinin düzenlenmesi ile çevreyle ilgili yapı tasarımı gibi farklı konular çalışma kapsamında göz önünde bulundurulmuştur.

İzmir'in Urla İlçesi'nin sürdürülebilir gelişme potansiyelinin belirlenmesi için önemli bulgular elde edilmiş ve Urla'da yaşayan yerel halkın sürdürülebilir gelişme hakkındaki bilgi düzeyi, yerel halkın çevre bilinci ve yerel halkın yerel yönetimden olan beklentileri ortaya konmuştur. Öncelikle, kavramsal olarak literatürde sürdürülebilir gelişme, sürdürülebilir kalkınma hedefleri, Avrupa yeşil kentleri ve yerel halk ilişkisini ortaya koyan çalışmalar incelenmiştir. Kentlerde sürdürülebilirlik kavramı ve örnekleri ele alınmıştır. Bu bağlamda, sürdürülebilir gelişme sağlanmasında yerel halkın rolü ve önemini anlamak için Urla örneği ele alınmış. Urla'daki yerel halkın çevre bilinci ve yerel yönetimden beklentilerini belirleyebilmek için anket çalışması uygulanmıştır.

Elde edilen bulgular özetle şu şekildedir:

- $\quad$ Ankete katılanların \%43' ünün üniversite mezunu olduğu saptanmıştır. Urla'da yaşayan yerel halkın eğitim düzeyinin yüksek olması, sürdürülebilir gelişme sağlanabilmesi için büyük potansiyel oluşturmaktadır.

- Katılımcıların \%52,5'i, sürdürülebilir gelişme hakkında fikri olduğunu belirtmiştir. Bu sonuç da Urla'da çevre bilinci olan ve sürdürülebilir gelişme sağlanabilmesi için bilgi düzeyi olan bir yerel halkın varlığını göstermektedir.

- Yapılan anket çalışması sonucunda, katılımcıların \%58,6'sı yerel yönetimin sürdürülebilir gelişme ile ilgili etkinlikler yaptığını belirtmektedir.

- $\quad$ Sürdürülebilir gelişme hakkında fikir sahibi olan katılımcılardan sadece $\% 24,7$ 'si yerel yönetimin etkinliklerini yeterli bulmaktadır. Bu sonuç da yerel yönetimin sürdürülebilir gelişme ile ilgili daha fazla etkinlik yapması gerektiğini göstermektedir.

- Sürdürülebilir gelişme hakkında fikir sahibi olan katılımcıların \%31,9'u yerel yönetimin sürdürülebilir gelişme ile ilgili etkinliklerinde yer aldığını söylerken, büyük çoğunluk aksi yönde fikir belirtmiştir. 
- Sürdürülebilir gelişme hakkında bilgi sahibi olmayan katılımcıların $\% 90,1$ 'i yerel yönetimin sürdürülebilir gelişme ile ilgili etkinlikler yapması gerektiğini düşünmektedir.

- Katılımcıların \%78,5'i sürdürülebilir gelişme ile ilgili etkinlikler yapılırsa, bu etkinliklere katılacaklarını belirtirken, \%13,8'i katılmayacaklarını söylemiştir. Bu rakam Urla'da yaşayan yerel halkın sürdürülebilir gelişme sağlanabilmesi için yapılacak etkinliklere katılmaya çok istekli olduğunu göstermektedir.

- Katılımcıların \%22,1'i yerel yönetimin ulaşım ile ilgili hizmetlerini iyi olarak değerlendirirken, \%40,9'u ise yönetimin bu konudaki hizmetini yeterli bulmamaktadır. $\mathrm{Bu}$ sonuç da yerel halkın yerel yönetimden ulaşım ile ilgili beklentileri olduğunu ortaya koymaktadır.

Yapılan literatür taraması ve anket çalışması sonucunda, sürdürülebilir gelişme sağlanabilmesinde yerel halkın katılımının ve rolünün çok büyük önem taşıdığ anlaşılmaktadır. Urla'da yaşayan yerel halkın eğitim düzeyi ve sürdürülebilir gelişme ile ilgili bilgi düzeyinin yüksek olması, Urla'da sürdürülebilir gelişme sağlanabilmesi için büyük potansiyel taşımaktadır. Araştırma sonucunda, yerel halkın sürdürülebilir gelişme ile ilgili daha fazla etkinliklerin düzenlenmesi yönünde yerel yönetimden beklentileri vardır. Ayrıca yerel halk, yerel yönetimin sürdürülebilir gelişme ile ilgili etkinliklerini yeterli bulmamaktadır. Sürdürülebilir gelişme ile ilgili daha fazla etkinliklere yer verilecek olunursa, yerel halk bu etkinliklere katılmaya isteklidir. Urla'da çeşitli festivaller ve sosyal etkinliklerin yapılması, var olan doğal, tarihi ve kültürel kaynakların korunması, yerel halkın kalkınması için büyük önem taşımaktadır.

$\mathrm{Bu}$ araştırma sonuçları, Urla'daki yerel halkın sürdürülebilir gelişme sağlanabilmesi için düzenlenecek etkinliklere destek olabileceğini ortaya çıkarmıştır. Ayrıca, Urla'da yaşayan yerel halkın eğitim ve bilgi düzeyinin yüksek olması da, sürdürülebilir gelişme sağlanabilmesi için çok önemlidir. Yapılan araştırma sonucunda, yerel yönetimin yenilenebilir enerji kaynaklarının kullanımını teşvik edecek bazı uygulamalar getirmesi gerektiğini ortaya çıkarmıştır. Yerel yönetimin ulaşımda daha çevreci alternatifleri teşvik etmesi gereklidir. Ayrıca, yerel halkın daha etkin rol üstlenmesi ve karar alma süreçlerine de dahil olmaları gerekmektedir. Bu durum, halkın eğitim ve çevre ile ilgili bilgi düzeyinin yüksek olması ile ilişkilendirilir. Urla'da sürdürülebilir gelişme ile ilgili yapılacak etkinliklere yerel halkın destek olma potansiyelinin yüksek olduğu anlaşılmaktadır. Ancak bu potansiyelin başarılı şekilde uygulanabilmesi için yerel yönetimin, sivil toplum örgütlerinin ve yerel halkın birbirleriyle dayanışma halinde çalışmaları gerekmektedir.

Doğru projeler ve etkinliklerle, yerel halkta var olan potansiyelden faydalanmak mümkündür. Sürdürülebilir gelişmenin sağlanabilmesinde en önemli unsur eğitimdir ve bu unsurdan faydalanılması önerilir. Yerel halka çevre koruma ve sürdürülebilir gelişmeyle ilgili eğitimlerin verilmesi ve belli dönemlerde çevre koruma gibi etkinliklerin yapılması gerekmektedir. Bir diğer öneri de, Urla'daki 
enginar festivali ve bağ bozumu gibi etkinliklerin sürdürülebilirliğinin sağlanması ve bunlara benzer festivaller ile çevre etkinliklerinin arttırılmasıdır. Festivaller ve çevre ile ilgili yapılan etkinlikler sayesinde hem yerel halk ürettikleri ürünleri pazarlayarak kalkınma fırsatı bulabilecek, hem de, Urla'nın tarihten gelen doğal, kültürel özelliklerinin devamlılığını sağlayabileceklerdir. Doğal, kültürel ve tarihi birçok zenginliğe sahip olan Urla, yerel halkın eğitimi, çevre bilinci sayesinde sürdürülebilir gelişme sağlanabilmesi için büyük bir potansiyele sahiptir.

\section{Kaynaklar}

Atıl, A., Gülgün, B., ve Yörük, İ. (2005). Sürdürülebilir kentler ve peyzaj mimarlığı. Ege Üniversitesi Ziraat Fakültesi Dergisi, 42(2), 215-226.

Beatley, T. (ed.), (2012). GreenCities of Europe: Global Lessons on GreenUrbanism, Island Press: 2012, DOI 10.5822/978-1-61091-175-7_1

Birleşmiş Milletler Sürdürülebilir Kalkınma Konferansı, (2012), (United Nations Conference on Sustainable Development, Rio+20) https://sustainabledevelopment.un.org/rio20. (Erişim: 1 Ekim 2019

Bozlağan, R. (2005). Liderlik yaklaşımları ve belediyeler. Hayat Yayınları.

Capdevila, I., ve Zarlenga, M. I. (2015). Smart city or smart citizens? The Barcelona case. Journal of Strategy and Management, 8(3), 266-282.

Cole, R. J., Lindsey, G., ve Todd, J. A. (2000). Assessing life cycles: Shifting from green to sustainable design. Proc, Sustainable Buildings.

Gössling, S. (2013). Urban transport transitions: Copenhagen, city of cyclists. Journal of Transport Geography, 33, 196-206.

Kılıçoğlu, P. (2005). Türkiye'nin Çevre Politikalarında Sürdürülebilir Gelişme. Turhan Kitabevi, Anakara.

Pearce, A. R., ve Vanegas, J. A. (2002). Defining sustainability for built environment systems: an operational framework. International Journal of Environmental Technology and Management, 2(1-3), 94-113.

Pezikoğlu, F. (2016). Yeşil Ekonomi Göstergeleri ve Yeşil Etiketler. Süleyman Demirel Üniversitesi Ziraat Fakültesi Tarım Ekonomisi Bölümü, XII. Ulusal Tarim Ekonomisi Kongresi, http://www. tarimarsiv. com/wpcontent/uploads/2017/04/71. pdf (Erişim Tarihi: 02.10. 2018).

Pradhan, P., Costa, L., Rybski, D., Lucht, W., ve Kropp, J. P. (2017). A SystematicStudy of Sustainable Development Goal (SDG) Interactions, Earth'sFuture, 5, 1169-1179.

Roodman, D. M. (1999). Building a sustainable society. State of the World, 169188. In L. Brown and C. Flavin, eds., State of the World 1999. A Worldwatch Institute Report on Progress Toward a Sustainable Society. New York, London: W.W. Norton \&Co. 
Sürdürülebilir Kalkınma Türkiye http://surdurulebilirkalkinma.gov.tr/ (Erişim Tarihi: 14 Ekim 2019).

UNDP Türkiye http://www.tr.undp.org/content/turkey/tr/home/sustainabledevelopment-goals/goal-11-sustainable-cities-and-communities.html (Erişim Tarihi: 5 Ekim 2019).

Uslu, A. (2009). Sürdürülebilir Yeşil Kent Fikirleri, Örnekleri ve Türkiye için Dersler, 21. Uluslararası Yapı ve Yaşam Kongresi Bildiriler Kitabı, Bursa: TMMOB Mimarlar Odası Yayını, 49-58.

Uysal Oğuz, C. (2010). İklim değişikliği ile mücadelede yerel yönetimlerin rolü: Seattle örneği. Yönetim ve Ekonomi: Celal Bayar Üniversitesi İktisadi ve Idari Bilimler Fakültesi Dergisi, 17(2), 25-41.

Yücel Işıldar, G. (2012). 2011 Avrupa Yeşil Başkenti Hamburg: Eko-Kent Kriteleri ve Performans Göstergeleri Açısından İncelenmesi. Selçuk Üniversitesi İ̈BF Sosyal ve Ekonomik Araştırmalar Dergisi, 23, 241-262.

Zeemering, E. S. (2009). What does sustainability mean to city officials?.Urban Affairs Review, 45(2), 247-273. 